\title{
Technical Basis Document (TBD) and User Guides
}

\author{
P. J. Chiaro, JrREGEIVED \\ SEP 291998 \\ OSTI
}

WANAGED AND OPERATED BY

LOCKHEEO WARTIN ENERGY RESEARCH CORPORATION FOR THE UNTED STATES

DEPARTIEEY OF ENEREY 
This report has been reproduced directly from the best available copy.

Available to DOE and DOE contractors from the Office of Scientific and Technical Information, P.O. Box 62, Oak Ridge, TN 37831; prices available from (615) 576-8401.

Available to the public from the National Technical Information Service, U.S. Department of Commerce, 5285 Port Royal Rd., Springfield, VA 22161.

This report was prepared as an account of work sponsored by an agency of the United States Government. Neither the United States nor any agency thereof, nor any of their employees, makes any warranty, express or implied. or assumes any legal liability or responsibility for the accuracy, completeness. or usefulness of any information, apparatus, product, or process disclosed, or represents that its use would not infringe privately owned rights. Reference herein to any specific commercial product, process, or service by trade name, trademark, manufacturer, or otherwise, does not necessarily constitute or imply its endorsement, recommendation, or favoring by the United States Government or any agency thereof. The views and opinions of authors expressed herein do not necessarily state or reflect those of the United States Government or any agency thereof. 


\section{DISCLAIMER}

This report was prepared as an account of work sponsored by an agency of the United States Government. Neither the United States Government nor any agency thereof, nor any of their employees, makes any warranty, express or implied, or assumes any legal liability or responsibility for the accuracy, completeness, or usefulness of any information, apparatus, product, or process disclosed, or represents that its use would not infringe privately owned rights. Reference herein to any specific commercial product, process, or service by trade name, trademark, manufacturer, or otherwise does not necessarily constitute or imply its endorsement, recommendation, or favoring by the United States Government or any agency thereof. The views and opinions of authors expressed herein do not necessarily state or reflect those of the United States Government or any agency thereof. 


\section{DISCLAIMER}

Portions of this document may be illegible in electronic image products. Images are produced from the best available original document. 
Instrumentation and Controls Division

\title{
TECHNICAL BASIS DOCUMENT (TBD) AND USER GUIDES
}

\author{
P. J. Chiaro, Jr.
}

Date Published: September 1998

\author{
Prepared by \\ OAK RIDGE NATIONAL LABORATORY \\ Oak Ridge, Tennessee 37831-6285 \\ Managed by \\ LOCKHEED MARTIN ENERGY RESEARCH CORP. \\ for the \\ U.S. DEPARTMENT OF ENERGY \\ under contract DE-AC05-96OR22464
}




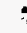


CONTENTS

BACKGROUND

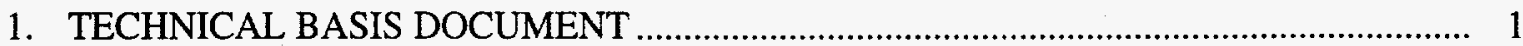

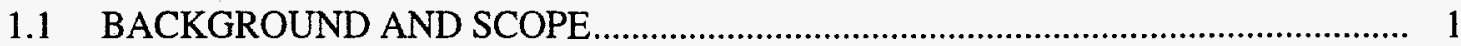

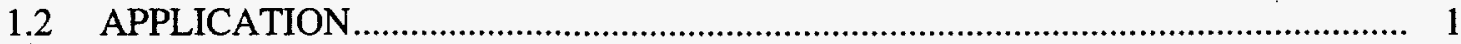

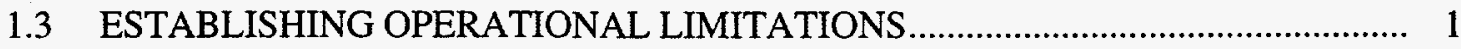

1.3.1 Radiation Types .......................................................................................... 1

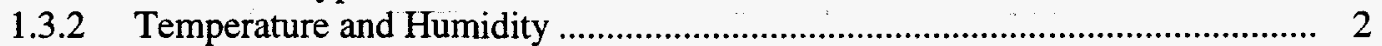

1.3.3 Radio Frequency and Magnetic Fields ........................................................ 2

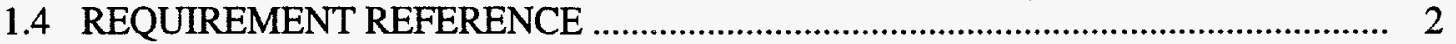

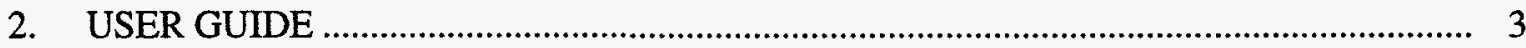

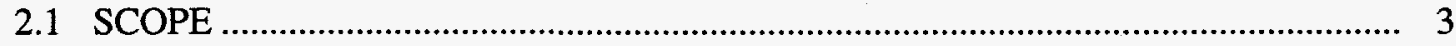

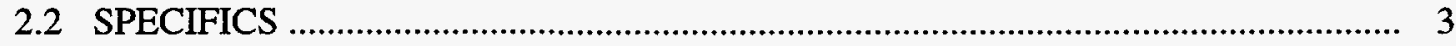

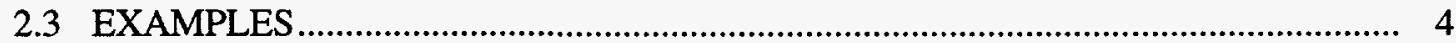

3. INSTRUMENT USER GUIDE, EBERLINE MODEL RO-20 ….................................. 5

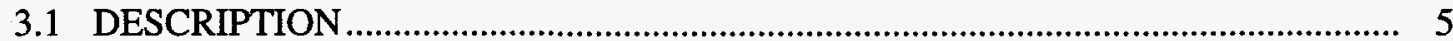

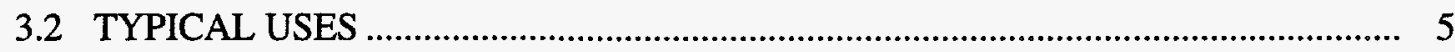

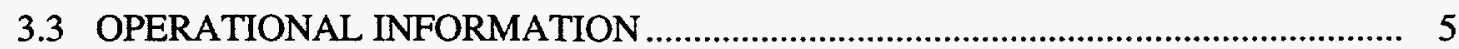

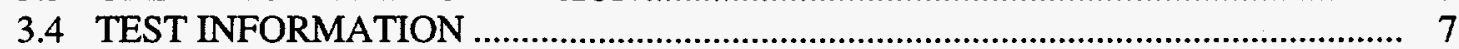

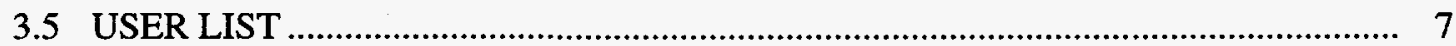

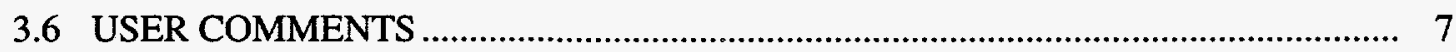

4. INSTRUMENT USER GUIDE, BICRON SURVEYOR M WITH PANCAKE GM PROBE 8

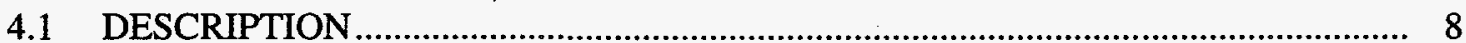

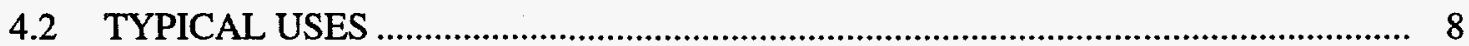

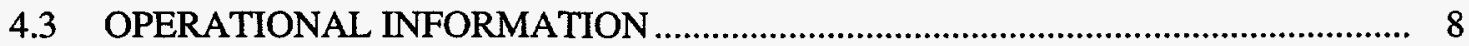

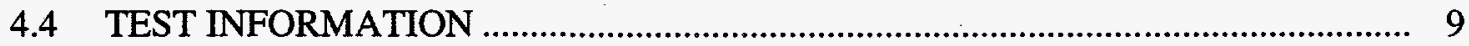

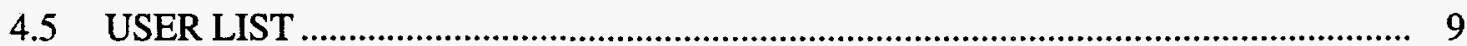

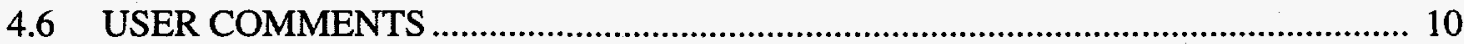

5. INSTRUMENT USER GUIDE, LUDLUM MODEL 12 WITH A MODEL 43-65 PROBE.. 11

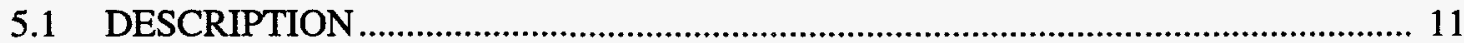

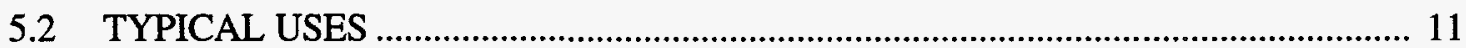

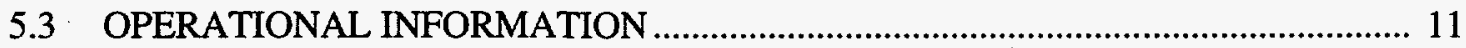

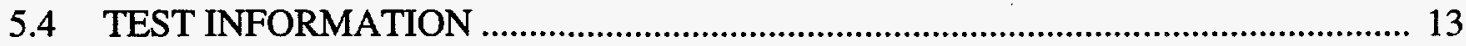

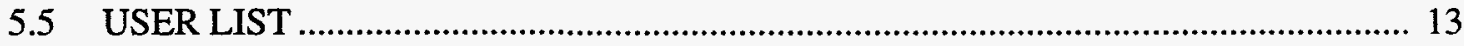

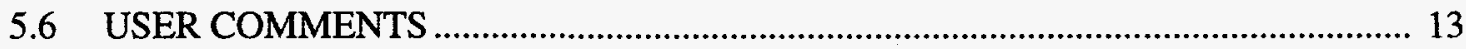





\section{BACKGROUND}

To ensure that radiation protection instruments are appropriate for (1) "the type(s), levels, and energies of the radiation(s) encountered, "and (2) "for existing environmental conditions," [10 CFR 835.401(c)(2) \& (3)], some U. S. Department of Energy (DOE) facilities have developed Technical Basis Documents (TBDs) and Instrument User Guides. Most are paper-based and not easily updated or shared.

Due to the need to share information, the development of a standard TBD and a web-based User Guide format was needed. The combination of both documents should help those involved in the purchase, approval, and use of radiation instruments with ensuring that a specific instrument model is appropriate for use at their facility. 
.

-

,

.

. 


\section{TECHNICAL BASIS DOCUMENT}

\subsection{BACKGROUND AND SCOPE}

A Technical Basis Document (TBD) should provide the background information for establishment of an instrument's operational requirements. Due to the amount and location of DOE facilities, no one set of requirements is possible. Operational requirements will vary based on the local environments and missions at each facility. Environmental conditions that can affect an instrument's operations are ambient temperature, humidity, and radio frequency, and to a lesser extent, magnetic fields, and interfering ionizing radiations. Consideration should also be made regarding how an instrument is to be used. If an instrument will be transported around the facility, vibration and shock can cause problems if they are not addressed in the TBD.

This document provides guidance for the development of a TBD.

\subsection{APPLICATION}

This document applies to radiation instruments used for personnel and equipment contamination monitoring, dose rate monitoring, and air monitoring.

\subsection{ESTABLISHING OPERATIONAL LIMITATIONS}

Tests performed by instrument manufacturers and independent facilities have found that certain environmental conditions can cause detrimental effects on a radiation instrument's ability to operate correctly. Observable effects usually include reduced response, increased response, erratic response, or no response. Without prior knowledge of these operational limitations, instruments could be placed into service that are not appropriate for the expected environmental conditions.

The TBD should contain specific information about the expected environmental conditions and information about the radiation types and levels expected to be encountered at the facility. The following sections provide guidance in a format that can be used to establish a facility-specific TBD.

\subsubsection{Radiation Types}

This section should contain a statement regarding the types of radiation encountered at the facility, i.e., alpha, beta, gamma, and/or neutron. Information about expected energy levels or isotopes is also suggested.

\section{Example \\ Expected radiation types: Beta, Gamma. Common Isotopes: ${ }^{137} \mathrm{Cs},{ }^{60} \mathrm{Co},{ }^{90} \mathrm{Sr} /{ }^{90} \mathrm{Y}$}

Interfering Ionizing Radiations-An instrument's response to radiations other than those it was calibrated for should be known. Typically, radiation instrumentation users will be the personnel who are most aware of the various radiations at the facility. 
Example

Instruments shall be capable of monitoring alpha radiation in the presence of beta-gamma and neutron radiation; beta-gamma radiation in the presence of alpha and neutron radiation; and neutron radiation in the presence of alpha and beta-gamma radiation.

\subsubsection{Temperature and Humidity}

Atmospheric conditions will obviously vary across the complex. Conditions within weather protected and non-weather protected locations should be used as a basis for establishing operating requirements. These can usually be obtained from local weather records or through an analysis of individual operations within each location. Climatic information is also available in existing Military Standards, such as MIL-STD 810.

Besides minimum and maximum conditions, exposure times should be considered. Instruments used for brief periods at elevated temperature and high humidity should not be required to meet the same requirements as instruments used for extended periods of times in those conditions.

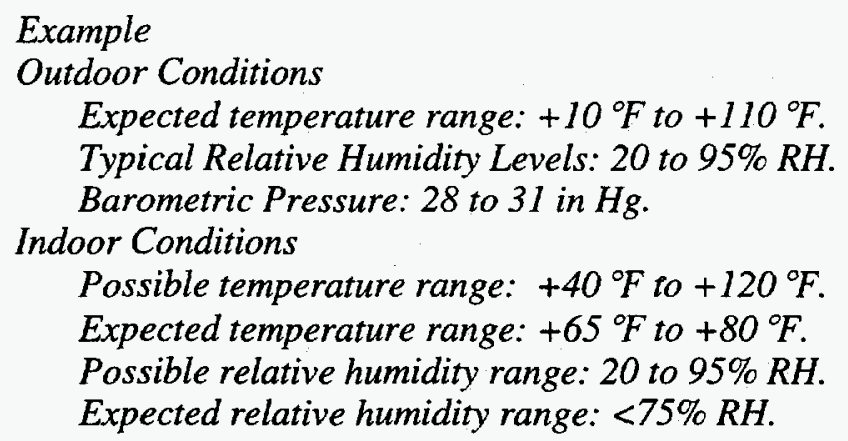

Note: Most facilities are environmentally controlled. These conditions may be external to the facilities while the operating environment is stable and controlled inside most facilities.

\subsubsection{Radio Frequency and Magnetic Fields}

Radio frequencies (non-ionizing radiation) and magnetic fields must be considered when evaluating radiation instrumentation. The prevalence of radios and cellular communication, as well as the use of other non-communications equipment that generate RF fields have increased the amount of interfering non-ionizing radiation in the environment. Documented susceptibilities include response effects (increased and decreased), and other operational changes such as alarm activation, display effects, etc. Information about local RF emitting devices such as their output frequency is necessary to ensure that the instrument is properly evaluated prior to use. The local communications group could probably provide the necessary information for the establishment of operating criteria.

The use of a scan evaluation over a frequency range of 20 or $80 \mathrm{MHz}$ to $1000 \mathrm{MHz}$ at 20 Volts/meter will ensure that an instrument's susceptibility is known.

\subsection{REQUIREMENT REFERENCE}

Title 10, Code of Federal Regulations, Part 835; Occupational Radiation Protection 


\section{USER GUIDE}

\subsection{SCOPE}

A User Guide is a consolidated source of information for an instrument model's operating limitations and susceptibilities. The information is based on controlled evaluations performed across the DOE complex, from field-use experience and manufacturer-supplied data. It can be used with a TBD to determine if a particular model meets the operational requirements of a specific facility, or as a means to share information about a particular model with other users.

The user guide is set up for use on the World Wide Web to enable easier updating and viewing. Access to the web site is uncontrolled, but registration is required when providing operational comments. A description of each user guide section follows.

\subsection{SPECIFICS}

A typical user guide is divided into the following sections:

1. Description-Describes the instrument model, probe/detector type, operating range(s), basic operating description, etc.

2. Typical Uses-Describes how the instrument is commonly used, i.e., dose rate measurement, contamination, etc.

3. Operational Limitations (test-based)_Provides a breakdown of the limitations on the instrument's use as determined by controlled testing performed either by the manufacturer or independent laboratory. The subsections are as follows:
3.1 Temperature,
3.2 Humidity,
3.3 Radio Frequency,
3.4 Magnetic Field,
3.5 Vibration and Shọck,
3.6 Energy Response,
3.7 Interfering Ionizing Radiations, and
3.8 Other Limitations.

4. Test Information-Provides links to appropriate testing information available on the World Wide Web.

5. User List-Provides a listing of the instrument's current users. The list is updated as needed and used to notify interested people of new information regarding a specific instrument model automatically, as needed.

6. User Comments-Contains a list of field-use observations and experiences provided by other users. All comments are shown by date and user name. Each comment is reviewed before being added to the users guide. 


\subsection{EXAMPLES}

Three example user guides are attached as Appendices 1 through 3.

Appendix 1, Eberline RO-20

Appendix 2, Bicron Surveyor with Pancake GM Probe

Appendix 3, Ludlum Model 12 with a 43-65 Probe 


\section{INSTRUMENT USER GUIDE}

EBERLINE MODEL RO-20

\subsection{DESCRIPTION}

The Eberline Model RO-20 is a portable, battery powered air ionization chamber used to detect beta, gamma, and x-ray radiation. It has five linear ranges of $0-5,0-50$, and $0-500 \mathrm{mR} / \mathrm{hr}$, and $0-5$, and $0-50 \mathrm{R} / \mathrm{hr}$. The ion chamber is vented to the atmosphere so that changes in atmospheric pressure will affect the response of the instrument.

\subsection{TYPICAL USES}

The Eberline RO-20 is typically used to perform dose rate surveys. It is commonly used to establish stay times or monitor areas to establish protection boundaries.

\subsection{OPERATIONAL INFORMATION}

Temperature

Operating Range

Manufacturer: $-40^{\circ} \mathrm{F}$ to $+140^{\circ} \mathrm{F}\left(-40^{\circ} \mathrm{C}\right.$ to $\left.+60^{\circ} \mathrm{C}\right)$

Limitations

Available Testing: $-10^{\circ} \mathrm{C}$ to $50^{\circ} \mathrm{C}\left(+14^{\circ} \mathrm{F}\right.$ to $\left.+122^{\circ} \mathrm{F}\right)$

RO-20s can be susceptible to rapid changes in temperature especially when operated using the most sensitive range. The susceptibility is greater when Precautions exposed to changes that are lower than ambient $\left(22^{\circ} \mathrm{C}\right.$ to $\left.-10^{\circ} \mathrm{C}\right)$.

When it is necessary to operate an RO-20 after a temperature change of $>10^{\circ} \mathrm{C}$, it is recommended that the instrument reach thermal equilibrium prior to use.

Humidity

Operating Range

Manufacturer: Operable from 0 to $95 \%$, non-condensing

Available Testing: Exposed to $95 \%$ (non-condensing) for eight hours, and

Limitations $40 \%$ for 4 hours at $22 \pm 2{ }^{\circ} \mathrm{C}$.

Precautions

None for non-condensing atmospheres.

None.

\section{Radio Frequency}

Operating Range

Manufacturer: None provided.

Available Testing: Tested at 20 Volts/meter over a frequency band from $100 \mathrm{kHz}$ to $1000 \mathrm{MHz}$ and at $2450 \mathrm{MHz}$. 
Limitations

Some susceptibility may exist from 730 to $800 \mathrm{MHz}$ when operated using the most sensitive range.

Precautions

The RO-20 should not be operated using the most sensitive range in RF fields from 730 to $800 \mathrm{MHz}$.

Magnetic Field

Operating Range

Manufacturer: None provided.

Available Testing: 10 Gauss (10 Oersted) DC, and $60 \mathrm{~Hz}$ (1.26 Gauss) AC

Limitations in two orientations.

Precautions

None for field intensities up to those performed during testing.

If field conditions are unknown, it is recommended that a response check be performed prior to use at the location of use. Some effect may be seen when operated in high magnetic fields.

\section{Vibration and Shock}

Operating Range

Manufacturer: None provided.

Available Testing: Exposure to $15 \mathrm{~Hz}$ and $28 \mathrm{~Hz}$ at $2 \mathrm{G}$ in three orientations. No shock information available.

Limitations

Typical electronic equipment handling procedures.

Precautions

It is recommended that a response check be performed prior to use if it is suspected that the unit had been exposed to an extreme vibration condition or shock event.

\section{Energy Response}

Note: The following information is provided by the manufacturer.

Limitations

Information is normalized to ${ }^{137} \mathrm{Cs}$ calibration, slide closed and facing the source.

Photon

$\pm 30 \%$ from $8 \mathrm{keV}$ to $1.3 \mathrm{MeV}$ with open slide facing the source.

$\pm 15 \%$ from $33 \mathrm{keV}$ to $1.3 \mathrm{MeV}$ with the slide closed.

$\pm 15 \%$ from $55 \mathrm{keV}$ to $1.3 \mathrm{MeV}$ through the side of the case.

Beta

Uranium slab $-30 \%$ of the true $\mathrm{mrad} / \mathrm{hr}$ field behind $7 \mathrm{mg} / \mathrm{cm}^{2}$ window with RO-20 resting on the slab, slide open.

${ }^{90} \mathrm{Sr}^{90}{ }^{90} \mathrm{Y}$ - approximately $93 \%$ of true $\mathrm{mrad} / \mathrm{hr}$ field at $30 \mathrm{~cm}$ with the slide open.

Fast Neutron Response (PuBe)

$8 \%$ in $\mathrm{mR} / \mathrm{hr}$ of true neutron field in $\mathrm{mrem} / \mathrm{hr}$.

Note - Available test results indicated a rate of $6 \%$. 


\author{
Interfering Ionizing Radiations \\ Operating Range \\ Manufacturer: N/A. \\ Limitations \\ Available Testing: N/A. \\ N/A. \\ Precautions
}

This instrument is designed to respond to $\mathrm{x}$-ray, gamma, and beta. It also responds to neutrons. Information regarding its neutron response is available in the energy response section.

\title{
Other Limitations
}

The RO-20 has been revised since its inception. Revisions were made to address fundamental susceptibilities with changes in temperature. Questions regarding currently available units should be addressed to the manufacturer.

Questions not addressed directly in this document should be addressed to other users or the manufacturer.

\subsection{TEST INFORMATION}

PNNL - http://www.pnl.gov/health/health_prot/instrume.html

ORNL - http://www.ic.ornl.gov/centers/ite/hpinfo.htm

LANL - http://esh-4.lanl.gov/ric1/result.htm

\subsection{USER LIST}

This section provides a listing of the instrument's current users. The list is updated and used to notify people of new information regarding a specific instrument model, as needed.

\subsection{USER COMMENTS}

This section contains a list of field-use observations and experiences that have been provided by other users. All comments are shown by date and user name. Each comment is reviewed before being added to the TBD.

User Name Date Comment Key Word (Main Issue of Comment) 


\section{INSTRUMENT USER GUIDE}

\section{BICRON SURVEYOR M WITH PANCAKE GM PROBE}

\subsection{DESCRIPTION}

The Surveyor $M$ is a portable, battery operated count rate meter. The pancake GM tube is a Bicron Model PGM. The ranges are X $1(0-500 \mathrm{cpm})$, X $10(0-5000 \mathrm{cpm})$, X $100(0-50000$ $\mathrm{cpm})$, and $X 1000(0-500000 \mathrm{cpm})$. The $X 1000$ range is not recommended for use with this instrument/detector combination.

\subsection{TYPICAL USES}

The Bicron Surveyor M/PGM is typically used for beta/gamma contamination surveys. It is commonly used to check for contamination on equipment or personnel.

\subsection{OPERATIONAL INFORMATION}

Temperature

Operating Range

Manufacturer: $-20^{\circ} \mathrm{C}$ to $+50^{\circ} \mathrm{C}\left(-29^{\circ} \mathrm{C}\right.$ to $\left.+122^{\circ} \mathrm{F}\right)$

Limitations

Available Testing: $-10^{\circ} \mathrm{C}$ to $50^{\circ} \mathrm{C}\left(+14^{\circ} \mathrm{C}\right.$ to $\left.+122^{\circ} \mathrm{F}\right)$

Precautions

None when operated within the stated temperature range.

If operation is required outside the stated temperature range, a response check should be performed after the instrument reaches thermal equilibrium with the ambient conditions prior to use.

Humidity

Operating Range

Manufacturer: $5 \%$ change in reading from 10 to $95 \%$ relative humidity:

Available Testing: Exposed to 95\% (non-condensing) for eight hours, and $40 \%$ for 4 hours at $22 \pm 2{ }^{\circ} \mathrm{C}$.

Limitations

None for non-condensing atmospheres.

Precautions

None.

\section{Radio Frequency}

Operating Range

Manufacturer: None provided.

Available Testing: Tested using a scan from $0.3 \mathrm{MHz}$ to $35 \mathrm{MHz}$, and at $140 \mathrm{MHz}$ at 50 volts/meter. Also tested at $915 \mathrm{MHz}$ and $2.45 \mathrm{GHz}$ at 0.4 Limitations watts $/$ meter $^{2}$ and 2.0 watts $/$ meter $^{2}$ respectively.

None.

Precautions

None. If field conditions are unknown, it is recommended that a response check be performed prior to use at the location of use. 
Magnetic Field

Operating Range

Manufacturer: None provided.

Limitations

Available Testing: 10 Gauss DC.

This instrument/probe combination shows a susceptibility to magnetic fields when operated using the $\mathrm{X} 1$ range. Other, less sensitive ranges do

Precautions not seem susceptible.

The instrument/probe combination should not be operated using the $\mathrm{X} 1$ range in areas where magnetic fields may exist. If field conditions are unknown, it is recommended that a response check be performed prior to use at the location of use.

Vibration and Shock

Operating Range

Manufacturer: Up to $100 \mathrm{~g}$ per lightweight machine of MIL-STD 202C, method 202B (shock). Up to $5 \mathrm{~g}$ in three mutually orthogonal axes at one or more frequencies from 10 to $33 \mathrm{~Hz}$.

Available Testing: Exposure to $15 \mathrm{~Hz}$ and $28 \mathrm{~Hz}$ at $2 \mathrm{G}$ in three Limitations orientations. No shock information available.

Precautions

Typical electronic equipment handling procedures.

It is recommended that a response check be performed prior to use if it is suspected that the unit had been exposed to an extreme vibration condition or shock event.

Energy Response

No information available.

Interfering Ionizing Radiations

This instrument/probe combination responds to most all ionizing radiations.

Other Limitations

None.

\subsection{TEST INFORMATION}

ORNL - http://www.ic.ornl.gov/centers/ite/hpinfo.htm

\subsection{USER LIST}

This section provides a listing of the instrument's current users. The list is updated and used to notify people of new information regarding a specific instrument model, as needed. 


\subsection{User Comments}

This section contains a list of field-use observations and experiences provided by other users. All comments are shown by date and user name. Each comment is reviewed before being added to the TBD.

User Name Date Comment Key Word (Main Issue of Comment)




\section{INSTRUMENT USER GUIDE}

\subsection{DESCRIPTION}

The Ludlum Model 12 is a portable, battery operated count ratemeter. The Ludlum Model 43-65 detects alpha radiation. The Ludlum Model 12 has a scale of $0-500$ counts per minute with four range multipliers; X1, X10, X100, and X1000.

\subsection{TYPICAL USES}

The Model 12/43-65 instrument combination is typically used to do alpha surface contamination surveys. It is commonly used to check for contamination on equipment or personnel.

\subsection{OPERATIONAL INFORMATION}

This section provides a breakdown of the limitations on the instrument's use as determined by controlled testing, or as stated by the manufacturer.

Temperature

\section{Operating Range}

Manufacturer: $-40^{\circ} \mathrm{C}$ to $50^{\circ} \mathrm{C}\left(-40\right.$ to $\left.122^{\circ} \mathrm{F}\right)$

Available Testing: $-10^{\circ} \mathrm{C}$ to $50^{\circ} \mathrm{C}\left(+14\right.$ to $\left.+122^{\circ} \mathrm{F}\right)$

Limitations

The instrument is susceptible to rapid changes in temperature especially when operated using the $\mathrm{X} 1$ range. The $\mathrm{X} 1$ is also affected when ambient temperatures are less than $+10^{\circ} \mathrm{C}\left(+50^{\circ} \mathrm{F}\right)$ or greater than $+40^{\circ} \mathrm{C}\left(+104^{\circ} \mathrm{F}\right)$.

Precautions

If operation is required outside of the stated temperature range, a response check should be performed after the instrument reaches thermal equilibrium with the ambient conditions.

This instrument/probe combination should not be used on the $\mathrm{X} 1$ range when the ambient temperature is less than $+10^{\circ} \mathrm{C}\left(+50^{\circ} \mathrm{F}\right)$ or greater than $+40^{\circ} \mathrm{C}\left(+104^{\circ} \mathrm{F}\right)$.

When exposing this instrument/probe combination to a temperature change of greater than $10 \sim C$ is necessary, it is recommended that the instrument reach thermal equilibrium and then be successfully response checked before use.

Humidity

Operating Range

Manufacturer: No information available.

Available Testing: Exposed to $95 \%$ (non-condensing) for eight hours, and $40 \%$ for 4 hours at $22 \pm 2{ }^{\circ} \mathrm{C}$. 
Limitations

None for non-condensing atmospheres.

Precautions

None.

$\underline{\text { Radio Frequency }}$

Operating Range

Manufacturer: None provided.

Available Testing: Tested using a scan from $0.3 \mathrm{MHz}$ to $35 \mathrm{MHz}$, and at $140 \mathrm{MHz}$ at 50 volts/meter. Also tested at $915 \mathrm{MHz}$ and $2.45 \mathrm{GHz}$ at 0.4 watts $/$ meter $^{2}$ and 2.0 watts/meter ${ }^{2}$ respectively.

Limitations

The instrument/probe combination is susceptible to RF fields. Susceptibilities were indicated at frequencies below $35 \mathrm{MHz}$, and at 140

Precautions and $915 \mathrm{MHz}$, primarily on the $\mathrm{X} 1$ range.

The Ludlum Model 12 with a Ludlum Model 43-65 should not be operated in radio frequency fields on the $\mathrm{X} 1$ range. If field conditions are unknown, or when operated using other ranges, it is recommended that a response check be performed before use at the location of use.

Magnetic Field

Operating Range

Manufacturer: None provided.

Available Testing: 10 Gauss (10 Oersted) DC, and $60 \mathrm{~Hz}$ (1.26 Gauss) AC

Limitations in two orientations.

Precautions

The instrument/probe combination is susceptible to magnetic fields.

The Ludlum Model 12 with a Ludlum Model 43-65 should not be used in areas where magnetic fields exist.

Vibration and Shock

Operating Range

Manufacturer: None provided.

Limitations

Available Testing: No test information available.

Precautions

Typical electronic equipment handling procedures.

It is recommended that the instrument be response checked before use if it is suspected that the unit had been exposed to an extreme vibration condition or shock event.

Energy Response

N/A

Interfering Ionizing Radiations

Operating Range

Manufacturer: None.

Available Testing: Gamma - Exposed to $11.7 \mathrm{R} / \mathrm{hr}{ }^{137} \mathrm{Cs}$ gamma field.

Neutron - Exposed to a $1 \mathrm{rem} / \mathrm{hr}$ unmoderated ${ }^{252} \mathrm{Cf}$ neutron field. 


\section{Limitations}

The response of the Ludlum Model 12 with a Ludlum Model 43-65 was 2000 to 4000 counts per minute when exposed to the neutron field. No Precautions response was observed when exposed to the gamma field.

It is recommended that this instrument/probe combination not be used when neutrons are present.

\section{Other Limitations}

Questions not addressed directly in this document should be addressed to other users or the manufacturer.

\subsection{TEST INFORMATION}

This section provides links to national laboratory testing information available on the world wide web.

ORNL - http://www.ic.ornl.gov/centers/ite/hpinfo.htm

\subsection{USER LIST}

This section provides a listing of the instrument's current users. The list is updated and used to notify people of new information regarding a specific instrument model, as needed.

\subsection{USER COMMENTS}

This section contains a list of field-use observations and experiences provided by other users. All comments are shown by date and user name. Each comment is reviewed before being added to the TBD.

User Name Date Comment Key Word (Main Issue of Comment) 


\section{INTERNAL DISTRIBUTION}

1-2. P. J. Chiaro, Jr.

3. M. A. Phipps

7. M. C. Wright

4. R. T. Roseberry

8. Central Research Library

5. E. R. Tapp

9. ORNL Laboratory Records-RC

6. J. D. White

10-11. ORNL Laboratory Records-OSTI

EXTERNAL DISTRIBUTION

12. Murari Sharma, U.S. Department of Energy, EH-52, 19901 Germantown Road, Room 5057, Germantown, MD 20874 